\title{
The Dimensions of Soft Skills and CBT (Competency Based Training) on the Entrepreneurship Education in Agribusiness Vocational High School
}

\author{
Lili Marliyah $^{1}$, Sugiyo ${ }^{2}$, Masrukhi $^{3}$, Rusdarti ${ }^{4}$ \\ Graduate School, Universitas Negeri Semarang, Indonesia \\ Corresponding email: lilimarliyah@ rocketmail.com
}

\begin{abstract}
The problems of low level care and consistency on entrepreneurship education cause distortion in building students' entrepreneurship spirit. Identification of soft skills and CBT dimension is needed as the basic analysis in improving the effectiveness of entrepreneurship education. The purpose of this research was to understand the types of soft skills, the applied CBT concept, the involved actors, and the learning process. The methods used in this research were observation, interview, and documentation. Meanwhile, the technique of data analysis employed was interactive model. The results of this research showed: (1) the intense involved actors, (2) the type of entrepreneurship that was developed, namely entrepreneurship and productive teachers have not yet synergized, (3) the planning, implementation, and evaluation of learning still employed semi-modern conventional pedagogy, and were less contextual. The findings of this research can be used as basic policy in developing entrepreneurship education for related institutions by integrating the soft skills dimension and the application of CBT concept optimally to create students' entrepreneurship spirit on the level of personal maturity.
\end{abstract}

Keywords: soft skills, CBT, Entrepreneurship Education

\section{Introduction}

The industrial revolution 4.0 requires education in the current disruption era to be relevant and competitive in shaping the human "being" and not just "knowing". Entrepreneurship is an important phenomenon in various areas of educational institutions and levels of education. Entrepreneurship education is needed because society needs a culture of independence and responsibility (Linder, 2012). In addition, the number of entrepreneurs possessed by a country becomes the determinant of the progress, resilience, and competitiveness in the revolutionary era. Entrepreneurship education research becomes a strategic role in preparing the competing generations, youth empowerment (Aja-Okorie \& Adali, 2013), rural area development (Patel \& Chavda, 2013), urban area (Woolthuis et al., 2013), regional development (Muller , 2013), and economic growth (Braunerhjelm, 2010).

The current condition of distortion is shown in some studies (Priyanto, 2012, Mansyur, 2013 \& Susilowati, 2013). There is awareness of the importance of entrepreneurship education in Indonesia. Thus, there is a need to encourage related parties to conduct various innovations in the implementation of the education. However, the fact is the entrepreneurship education in Indonesia is not effective yet. It is indicated by the low entrepreneurship interest of high school graduates (Lutfiadi \& Rahmanto, 2011) and universities (Kurnianto \& Putra, 2012; Mopangga, 2014), entrepreneurship motivation (Seno, 2010), and the number of entrepreneurs in Indonesia (Priyanto, 2012) have a very low entrepreneurship interest, namely $22.63 \%$ for senior high school and $6.14 \%$ for college graduates.

The development of entrepreneurship education requires policy support from the central government level up to the implementers in entrepreneurial classes in order to maintain the availability of dynamic persons or entrepreneurs. The development of entrepreneurship is now increasingly contextual (Sarasvathy and Venkataraman, 2011). It requires integrated entrepreneurship education policy, especially for Vocational School (SMK) education level in strengthening soft skills dimension as well as the application of CBT concept oriented on developing personality mentality. This is in line with Presidential Instruction No. 9 Year 2016 which states that the quality of vocational education can be improved through entrepreneurial learning. Effective educational approach model is needed (Lindner, 2012) in accordance with the motto of SMK namely WCE (work, continue and entrepreneurship). It also gives rise to a new concept of entrepreneurship that is specific in the areas of (Onwurafor \& Enwelu, 2013) rural women entrepreneurship, 
(Asadi \& Kohan, 2011) ecotourism entrepreneurship, (Purnomo, 2014) minority entrepreneurship, ecopreneurship.

Therefore, this study aimed to answer how the dimensions of soft skills and CBT is realized in entrepreneurship education, the identification of developed soft skills, and the actors involved as well as the entrepreneurial learning process. Soft skills and CBT are the main focus for gaining useful trained knowledge to solve problems in society (Mark et al., 2014). The application of soft skills and CBT dimensions become the answer to the existence of distortion phenomenon on the implementation of entrepreneurship education because entrepreneurship soft skills in the field has not become the real soft skills. This results in the inhibition of the objectives of the vocational school as community economic empowerment (Estelles et al., 2016). Entrepreneurship becomes one of the alternative solutions in the economic crisis. On the other hand, entrepreneurship soft skills for vocational school students are still seen as complementary, even the training or industry practice is not yet targeted, and the highest unemployment data from vocational education level is $9.27 \%$ whencompared to the other educational levels (BPS, 2017). It indicates the improvement of education quality in vocational high school especially entrepreneurship education. In this case the dimensions of soft skills and CBT on entrepreneurship education in vocational schools can be blowing research to be followed up.

\section{Methods}

The research approach used was qualitative with ex post facto research type. The main data collection methods were interview, observation, and documentation. Interviews were conducted on the actors involved in entrepreneurship education, namely the principal, the vice principal for curriculum and student fields, the head of skill program, counselors, teachers, and students. Meanwhile, the data analysis was in form of qualitative descriptive with interactive analysis technique (data reduction, data display, and conclusion drawing / verification).

\section{Results and Discussion}

\section{The Type of Entrepreneurship Soft Skills Competence}

Entrepreneurship education held in Agribusiness vocational high school is an explanation of values that reflect the entrepreneurship attitude of graduates in the formulation of the school vision and mission namely dedication, broad-minded, skilled, independent, able to develop themselves and (Estelles, et al, 2016) help personal autonomy, leadership, innovation, creative stimulation and respect for other people's ideas. Entrepreneurship education can lead to an increase in the knowledge and skills needed to behave entrepreneurially (Klerk \& Dippenaar, 2003), as well as higher level of education can help improve the ability of aspiring entrepreneurs (Jiménez et al., 2015).

The strengthening of the entrepreneurship soft skills competence is not yet optimal because it is done in the subjects of workshop and entrepreneurship as well as on productive subjects in each skill program, so future studies should seek to investigate other entrepreneurship competence development programs from different geographical areas (Vilcov and Dimitrescu, 2015). Through the process of training, habituation and cultivation of entrepreneurial values through the practice of selling as well as visiting and internshipping in the business and industry world, vocational school graduates are expected to have entrepreneurial intention and attitude. In line with Vilcov and Dimitrescu (2015) professional orientation education activities should be directed towards specific skills training, while mental problems are the cause of the deterioration and unsuccessful entrepreneurship education. Entrepreneurship education is still dominantly hard skills. The application of the CBT concept is still dominant in psychomotoric, so the entrepreneurial mental strengthening is still not optimal.

\section{The Development of Entrepreneurship Soft Skills}

In the aspect of planning the development of entrepreneurship soft skills is done through process: (1) identification; (2) the formulation of objectives; (3) organizing teachers; and (4) socialization. The identification process of entrepreneurship soft 
skills in Agribusiness vocational high school is not yet optimal although the school audience is familiar with entrepreneurial soft skills limited only to the ability to "sell" as the ordinary people understanding of the competence of entrepreneurship soft skills. The source or basis of entrepreneurial soft skills planning that will be developed in Agribusiness vocational high school is in accordance with the vision and mission of the school. The vision of Agribusiness vocational high school is to produce graduates who are pious, professional, environmentally friendly and able to compete in the global era.

In the formulation of the goal of entrepreneurship education is in accordance with Ministry of Education and Culture Regulation (Permendikbud) number 59 year 2014 which is to create works and to develop products in the form of cultivation and processing through creating activities that are useful in everyday life, while its formal objectives are to develop creativity, to develop sense of caring and tolerance, independence and to encourage risk taking courage so that entrepreneurship can be created or learned (Krueger and Brazeal, 1994). However, the identification of entrepreneurship soft skills up to now has not been systematically integrated.

Ideally, the teacher of entrepreneurship education should be balanced between the scientific background, besides the entrepreneurship experience is also not less important (Woolfolk \& Acosta, 2016), plus students' participation in extracurricular activities can maintain the entrepreneurial spirit, precisely the experience is actually prerequisite that must be owned by an entrepreneurship teacher ideally.

\section{The Implementation of Entrepreneurship Soft Skills Development}

The implementation of entrepreneurship soft skills development in Agribusiness vocational high school can be seen from the learning process, school culture, and monitoring. The process of entrepreneurship learning includes the types of competence formulas to be achieved, teaching strategies or methods, media and learning tools and learning evaluations used to measure the success of entrepreneurship soft skills. Recommended teaching strategies are innovative pedagogy (Klapper, 2010), active pedagogy or not using conventional pedagogical design that tends to be teacher centered (Tasnim and Yahya, 2013), new approaches to entrepreneurship curriculum (Amiaya, 2013), business incubator, spin-off, entrepreneurial seats, business actors' role (Vaquero et al., 2016) and mentoring (Ismail et al., 2014).

The learning process is a tool used to escort the entrepreneurship soft skills to be implemented and grown in the habitual process (Cunha, et al, 2016) and the extension of professional teaching and technology development. The various entrepreneurial soft skills are developed primarily by subject teachers of entrepreneurship and productive subjects in every competency of agribusiness expertise. The selling competence is an integrated skill form of some of the entrepreneurship soft skills, among others are aspects of soft skills of courage, communication, risk-taking, and confidence. Rodríguez \& Ibarra (2016) state that the challenge is to develop tools and sources of technology in accordance with the principles of pedagogy.

\section{The Evaluation of Entrepreneurship Soft skills Development}

The evaluation process to measure the success of entrepreneurship soft skills is done from the institutional level. In this case the principal guards the entrepreneurship soft skills by conducting incidental monitoring. Furthermore, giving general evaluation and result are submitted incidentally on the daily rollcall activity. In addition, the evaluation on the development of entrepreneurship soft skills is conducted at the institutional level, such as the coordination and evaluation at the Teacher Working Group (MGMP) level of construction and entrepreneurship subjects. Measurement in the final stage is done with partial and holistic test models. Partial test is conducted on some departments that can not carry out entrepreneurship-based productive training, whereas for some skill programs are examined holistically as it is possible to carry out productive training with entrepreneurial based system.

\section{The Actors in the Development of Entrepreneurship Soft skills}

Teacher component is the determining factor in the implementation of 
entrepreneurship soft skills development in schools. Teachers should act as facilitators, dynamisators, motivators and catalysts for the development of entrepreneurship soft skills and focused on the principal and teacher training system first (Ruskovaara et al., 2016). The ability and competence of students in the skills of entrepreneurship soft skills are still not appropriate becuase their success in the courage test of taking risk at the tome of entrepreneurship soft skills training is less than $1 \%$ of each entrepreneurship class guided, as well as the ability of other entrepreneurship soft skills. The dimensions of soft skills and CBT can be enhanced through the synergy among the actors, especially (entrepreneurship teachers and productive teachers).

Some obstacles of entrepreneurship soft skills development are vocational high school curriculum is explicitly aimed not to be entrepreneur, the consistency of entrepreneurship soft skills development cannot be implemented, normative subject and adaptive subject teachers still do not synergize significantly in the development of entrepreneurship soft skills, and learning process of training courses become the main consent.

\section{CBT on Entrepreneurship Education in Agribusiness Vocational High School}

CBT is formative theory that can be used in vocational learning / vocational training. Competency Based Training (CBT) is a training approach that emphasizes what a person can do as a result of training (training outcome). It is expected that graduates can compete in the global market, have both entrepreneurship hard skills and soft skills competencies, (Purnomo, 2014), the ability to identify opportunities or to identify good ideas (Lumpkin \& Lichtenstein, 2005) the change of a value-added concept, and (Martin and Iucu , 2014) there is a change of entrepreneurial attitude, but the implementation of CBT is dominant in hard skills. The expectation is in accordance with the concept contained in strategic planning of Directorate of Vocational High School Education which states that the potential of vocational high school to increase national economic growth can be through the motto of WCE (work, continue, and entrepreneurship).

\section{Conclusion}

The type of entrepreneurship soft skills developed is the enhencement of the mission and vision (independence, able to compete in the global era and care for the environment) embodied in the competence of selling. The development of entrepreneurship soft skills is not yet optimal and its implementation is dominantly hard skills. The success of entrepreneurship education is the responsibility of entrepreneurship teachers and productive teachers as well as the need for synergy in the planning, the implementation, and the evaluation of learning that emphasizes on contextual and holistic approaches. The implications of the results of this study can be used as the basis of policy in developing entrepreneurship education for related institution to integrate soft skills dimension and application of CBT concept optimally to build student entrepreneurship spirit on maturity level of personality, in accordance with the goal of entrepreneurship education in Agribusiness vocational high school sector.

\section{References}

Aja-Okorie, U \& Adali, O. (2013). Achieving Youth Empowerment Through Repositioning Entrepreneurial Education In Nigerian Universities: Problems \& Prospects. European Scientific Journal. 9 (2), 113-132.

Asadi, A \& Kohan, M. F. Z. 2011. The role of Entrepreneurship on Ecotourism development. Proceedings. International Conference on Sociality and Economics Development, IPEDR

Braunerhjelm, P. (2010). Entrepreneurship, Innovation \& Economic Growth: Past Experiences, Current Knowledge \& Policy Implications. Available at: http:// entreprenorskapsforum.se/wpcontent/uploads/2013/03/WP_02.pdf. Downloaded on $3^{\text {rd }}$ of July 2014.

Central Jakarta Central Bureau of Statistics. (2017). Statistik Indonesia Tahun 2017. Jakarta Pusat : Central Bureau of Statistics. co-operation between schools \& businesses? South African Journal of Education. 23 (4), 319-322.

Cunha, C., et al. (2016). Entrepreneurship education: a tool for development of technological innovation. Education Tools for Entrepreneurship. 73-86. 
Estelles-Miguel, S.et al. (2016). Educating for Entrepreneurship: Application to the Business Services Marketing Subject. Education Tools for Entrepreneurship Springer International Publishing . 125-134. Available at https://doi.org/10.1007/978-3-319$24657-4 \quad 10$

Ismail, V. Y., \& Zain, E. (2014). The portrait of entrepreneurial competence on student

entrepreneurs. Procedia-Social and Behavioral Sciences. 169, 178-188.

Jiménez, A., et al. (2015). The Impact of Educational Levels on Formal and Informal Entrepreneurship. $B R Q$ Business Research Quartely. 18(3), 204-212.

Klapper, R. (2010). Innovations in Entre preneurship Teaching: The Use of

Klerk, J. K. S \& Dippenaar, A. (2003). Developing the next generation of potential entrepreneurs:

Kurnianto, B. S \& Putra, S. I. (2012). Menumbuh Kembangkan Minat Berwirausaha bagi Para

Lindner, J. (2012). Entrepreneurship Education between economic educational

Lumpkin, G. T \& Lichtenstein, B. B. (2005). The role of organizational learning in the opportunity-recognition process. Entrepreneurship Theory \& Practice. 29 (4), 451-472.

Mahasiswa di Lingkungan Perguruan Tinggi. Proceeding. Seminar \& Konferensi Nasional Manajemen Bisnis. 26 May.

Mansyur, M. (2013). Meningkatkan Minat Berwirausaha Melalui Program Pemagangan pada \ Dunia Industri bagi Mahasiswa IAIN Sunan Ampel Surabaya. Available at: http:// eprints.uinsby.ac.id/197/1/.

Downloaded on $30^{\text {th }}$ of June 2014.

Mark H. E. A., et al. (2014). The Effect of Science Process Skills Teaching Approach on Secondary School Students`Achievement in Chemistry in Nyando District, Kenya, Journal of Educational and Sosial Research. 5(6), 2240-0524

Mopangga, H. 2014. Faktor Determinan Minat Wirausaha Mahasiswa Fakultas Ekonomi dan Bisnis Universitas
Negeri Gorontalo. Trikonomika. 13 (1), 78-90.

Muller, S. (2013). Entrepreneurship \& Regional. Development: On The Interplay. Between Agency \& Context. Available at: https://Pure. Au.Dk/Ws/Files/74825510/Phd_Thesi s_Sabine_Mueller2. Pdf. Downloaded on $3^{\text {rd }}$ of July 2014.

Onwurafor, E. U \& Enwelu, I. A. (2013). Rural Women Entrepreneurship in Agro-Food Processing In Enugu State, Nigeria. International Journal of Research in Applied, Natural and Social Sciences. 1 (2), 13-30.

Patel, B \& Chavda, K. (2013). Rural Entrepreneurship in India: Challenge \& Problems. International Journal of Advance Research in Computer Science \& Management Studies. 1 (2), 28-37.

philosophy and key competence for lifelong learning. Initiative for Teaching Entrepreneurship (IFTE) \& the Impulse Centre for Entrepreneurship Education (eesi) of the Austrian Federal Ministry for Education, Arts \& Culture.

Priyanto, S. H. (2012). Entrepreneurial \& vocational learning in entrepreneurship education: Indonesian Non formal education perspective. Basic Research Journal of Business Management \& Accounts.1 (2), 30-36.

Purnomo, M. (2014). Alternatif Model Pendidikan Kewirausahaan Untuk Indonesia Timur. Proceeding. Seminar Nasional Indonesia Timur, Pusat Studi Kawasan Indonesia Timur (PUSKIT) Universitas Atma Jaya, Yogyakarta, $14^{\text {th }}$ of June.

Repertory Grids Within the French Grande Ecole Context. International Journal of Euro-Mediterranean Studies. 1 (1), 114-133.

Ruskovaara, E., Hämäläinen, M., \& Pihkala, T. (2016). HEAD teachers managing entrepreneurship education-Empirical evidence from general education. Teaching and Teacher Education. 55, 155-164.

Sarasvathy, S. D \& Venkataraman, S. (2011). Entrepreneurship as method: open questions for an entrepreneurial future. 
Entrepreneurship Theory \& Practice. $35,113-135$.

Seno, V. H. (2010). Pemodelan Motivasi Lulusan Perguruan Tinggi Menjadi Wirausaha Global pada Sektor Usaha Jasa di Wilayah Kota Depok. Available at: http://publication.gunadharma.ac.id/bit stream/123456789/3483/1.

Downloaded on $1^{\text {st }}$ of July 2014.

Susilowati, T. (2013). Pengembangan

Pendidikan Kewirausahaan dalam Upaya Menumbuhkan Budaya Wirausaha pada Siswa Sekolah
Menengah Atas (SMA) di Kabupaten Karanganyar. Jurnal Kewirausahaan dan Bisnis. 7 (12).

Tasnim, R \& Yahya, S. (2013). Playing Entrepreneurship: Can Games Make a Difference?. Entrepreneurial Practice Review. 2 (4), 4-16. vol.10. IACSIT Press, Singapore.

Woolfolk-Ruiz, D. E., \& Acosta-Alvarado, M. (2016). Experiential activities: A Tool to increase entrepreneurial skills. Education Tools for Entrepreneurship. 